\title{
Offering the "Sociological Eye" to Examine Ethical Egoism at an Illustrative Homeless Shelter for Men: A Pedagogical Exercise
}

\author{
J. Forbes Farmer, PhD \\ Professor of Sociology and Human Services \\ Franklin Pierce University
}

\begin{abstract}
This is an exploration into the philosophical realm of misplaced ethics at an illustrative homeless shelter where human service practitioners should be keeping better focus on delivering services to destitute men in a large industrial city. The question raised is whether or not the cause of the ethical egoism seen there, that results in problems typical of homeless shelters around the world, is structurally based. The problems result in mistrust of the shelter and a diminishment of services to a vulnerable population. Sociologically framed questions serve as a tool for the use of the case method of teaching.
\end{abstract}

Keywords: Homelessness, Homeless Shelters, Ethical Egoism, Case Method, Sociological Eye

\section{INTRODUCTION}

The essential concern of consequential moral theorists is that behavior should produce the best balance of good over evil. This could mean either the advancement of one's own interests over the interests of others or acting in a way that advances and results in the most happiness for all. The English philosophers Bentham and Mill brought this second interpretation, commonly referred to as utilitarianism, to their rationalizations for the promotion of social reform. Bentham (1879, [1789]) called this the "principle of utility" and Mill (1879) called it the "greatest happiness principle." This focus on the consequences of action was radical in their day, but in the twenty-first century it has become a powerful lens through which behavior can be analyzed and evaluated in many areas of everyday life, including management, decisionmaking and professionalism in the human services field that is guided by a code of ethics. When combined with the use of qualitative research and the "sociological eye" (Collins 1998), the actions described in case studies offer opportunities for students to break out of the isolation of the traditional classroom and become more successful at undertaking the social work mission of fighting the injustice experienced by the vulnerable and oppressed members of society.

The influence of the social sciences in investigating, analyzing and explaining social phenomena at different levels of intervention has been widely acknowledged for centuries. Psychology is the basis for much clinical work in the social work field (Brinca and Menezes 2019; Kamerman and Dolgoff 1984). Sociology is the other major social science to have established a long history of connectedness to social work (Callero 2013; Farmer 2014). However, sociologist Berger (1963) made it very clear over 50 years ago that sociology was not social work. Sociology is a systematic attempt to understand everyday life. Berger referred to sociologists as "Peeping Toms" who looked behind closed doors to reveal social structure in action. He believed that social work, on the other hand, is an occupational practice that uses the methodology and theory sociology offers. One sociologist, Collins (1998) described the "sociological eye" as the lens through which the "truth" about social situations can be demystified and explicated. 
What follows in this paper is the use of the "sociological eye" and sociologically framed questions combined with the time-honored qualitative case method to offer an opportunity to explore how the social work mission that is grounded in utilitarianism can be derailed when social worker action is based more on ethical egoism (Vaughn 2008) or the pursuit of one's own welfare first above the welfare of others. In the field of education, the use of cases is a preferred method of developing the cognitive processes of higher order thinking, especially when multiple issues are in play. Generally thought to have begun at the Harvard Business School (Jensen 2014), the case method spread to medicine (Boyle, Beardsley, Morgan and Rodriguez de Bittner 2007), social work (Brinca \& Menezes 2019; Packard \& Austin 2009; Rivas \& Hull 2004) and other professions.

\section{THE GENERAL PROBLEM}

One of the most vulnerable groups around the world that should be receiving more attention by social workers at the micro, mezzo and macro levels is the homeless population. Although it is difficult to obtain accurate numbers partly because the "homeless" is not a static group, it has been estimated that there are about 1.6 billion people around the world who lack adequate housing, and 150 million of them are homeless (Chamie 2017). This is about two percent of the world's population (Habitat 2015). There are estimated to be over 300,000 in England (Reynolds 2018), over 20,000 in Greece (Habitat 2015), almost 30,000 in Scotland (Shelter 2019), an estimated 700,000 in Peru (Leon and Kraul 2017), 100,000 in Russia (Chamie 2017), 25,000 in Israel (Surkes 2018), 200,000 in South Africa (Habitat 2015), about 600,000 in the United States (Henry, Mahathey, Morrill, Robinson, Shivji and Watt 2018), three million in China and India each (Chamie 2017) and so on. When one looks at the percentage of homeless in the total population of countries, New Zealand and the Czech Republic lead the list with between six and one percent (Chamie 2017). This social tragedy and policies towards its prevention and interventions are being vigorously pursued (Mackie 2015), at least in the developed countries.

The causes of homelessness around the world are complicated and multifaceted. They include the privatization of civic services, shortages of affordable housing, unplanned and rapid urbanization, poverty, mental illness, alcoholism, substance abuse, natural disasters, government housing policies, unemployment, family breakdown (Chamie 2017) and freezes and cuts to welfare payments (Reynolds 2018). While social scientists in the United States have done most of the research on homelessness, social scientists in other countries like the United Kingdom, France, Canada and Australia England are increasing their efforts to investigate the problem (Toro 2007).

The composition and characteristics of the homeless population continues to change due to macro and mezzo economic and demographic fluctuations. In the United States, for example, individual adults are the single largest group of homeless. Individual and unmarried men make up about 56 percent of the homeless. Many of these men have dependent children, physical health problems and experienced out-of-home placements as children (Toro, Hobden, Durham, Oko-Riebau and Bokszezanin 2014). Individual and unmarried females make up 25 percent (Institute of Medicine 1988). The number of homeless middle-aged men has been decreasing while families with young children are the fastest growing group (USCM 1987). Women and children from minority ethnic groups are also growing in numbers (DeVerteuil, May and von Mahs 2009). In short, the homeless population is quite heterogeneous.

The most effective and permanent solutions to, and prevention of, homelessness reside in legislatively written and adopted social policies and laws that support the development of more affordable housing, more effective approaches to drug and alcohol abuse, improving 
access to living wage jobs and quality education and affordable health care. Many countries have begun doubling down on this macro and mezzo paradigm. They argue that prevention is better than temporary relief or cures (Shelton 2012; Wilcox and Fitzpatrick 2010). This signals a shift away from focusing on homeless shelters (Mackie 2015). But the shelters still exist as temporary solutions and some (Culhane, Metraux and Byrne 2011) argue that homeless shelters should not go away and should coexist along with the prevention strategies.

There are thousands of homeless shelters around the world. For example, there are 80 in the Czech Republic, 70 in Denmark, over 100 in Poland and Romania, over 1,000 in England, over 80 in Spain (EOH 2018) and over 10,000 in the United States (IBIS 2019). And these shelters are all different. They serve different populations, offer different services, hold differing numbers of people, and have different rules. Some are long-term and some are short-term, some are only available in certain months. They could be private or public. Some are urban and some rural, some have waiting lists and some do not, some have referral connections to affordable housing and some do not, and so on. The one thing they all should have in common is a mission that reflects the social work code of ethics that mandates an improvement in the quality of life and personal well-being of the vulnerable homeless population that passes through their door, too often a revolving one.

Unfortunately, that is not always what happens. The following case describes a homeless shelter for men. Its problems are a composite of some documented issues with homeless shelters around the world. The homeless populations definitely need shelters, but the one presented here, and others it represents, needs fixing. There is considerable ethical egoism going on when it should be a more altruistic place. Is the root of this problem a structural one or is it rooted in human nature? The following case is offered for discussion and analysis through the "sociological eye" (Collins 1998).

\section{THE CASE}

\section{The Chelsea Place Shelter For Homeless Men}

The Chelsea Place Shelter provides safe, dignified temporary dormitory-style housing for 36 men (no children) at a time and serves hundreds of men each year. It is not only a homeless shelter, but distributes clothes, manages a food pantry, runs classes and prepares hot meals. Chelsea Place is located in a large brick building on a busy side street in a large industrial city and has a barely visible "Chelsea Place" sign on the door. It was founded by the Interfaith Council of the First Presbyterian Church 22 years ago. It is a private, nonprofit organization that receives a small government grant, a small municipal grant and relies mostly on volunteers and monetary and in-kind donations. It has a Board of Directors that includes a politician, a pharmacist, a university professor, an architect, a graphic artist, a minister, a clinical psychologist, a football coach and a local small business owner. Four of the Directors are women and five are men. There are four paid staff.

\section{The Mission}

Chelsea Place is listed in the Municipal Directory of Shelters as having a mission of providing temporary safe and quality shelter and service to single homeless men who want to break the cycle of homelessness, including those with a range of support needs. By reputation, Chelsea Place is clean, friendly and compassionate.

\section{The Rules}

There are 15 rules at Chelsea Place: (1) There is no discrimination, (2) No arsonists, sex offenders or men with a history of violence will be accepted, (3) No men who are intoxicated when they arrive will be accepted, (4) No drugs, alcohol or smoking is allowed, (5) No offensive 
weapons are allowed, (6) New residents are selected by lottery each day, (7) The number of residents cannot exceed 36, (8) Residents can only stay for 30 days, (9) Residents can return to Chelsea Place, but only after they have been away for 30 days, go through the lottery again and have proof of trying to find a job and permanent housing, (10) Residents must keep their bed area clean and neat, (11) No aggressive, violent, threatening or disruptive behavior, (12) Must be in the shelter by 9:30 PM, (13) No women are allowed in the resident living areas, (14) No pets and (15) Daily attendance at Christian service is required.

\section{The Staff}

The house manager is Dodger Mullins. He is 47, divorced, and has two sons living with him at Chelsea Place. He was a gang member in his youth and spent some time in juvenile hall for petty crimes, but found football and reentered high school. His guidance counselor helped him get into college; then he continued on to get his MSW. He has been with Chelsea Place for 14 years, the last three as house manager. He reports directly to the Board of Directors and is responsible for the budget, fund raising, community relations and establishing and maintaining connections with support agencies (hospitals, colleges, high schools, social clubs like Rotary or Annabel's House or the Soho Men's Club, job training programs, etc.). Mullins also supervises the three associate managers. He likes his work and until recently thought he was doing well.

Billy Kimber, an associate manager, is 38 years old, single, and has his BA in human services. He grew up on a farm and is the oldest of five children. Farm life was hard and he swore that after he was on his own that he would never go back to that life. When he was twelve his father died of alcohol related diseases. Two of Kimber's younger brothers are alcoholics. He recruits, trains, schedules and supervises class teachers and other program volunteers. There are 15-20 community volunteers for each of the three meal shifts. They not only feed the shelter residents, but 30-40 walk-in men each day. These volunteers prepare and serve food, clean the cafeteria, wash dishes, distribute clothes and other donated items.

Kate Falangen is the associate manager who runs the food pantry, solicits donations including food, clothes, books, sheets, towels, furniture, cleaning supplies and nonprescription drugs. Before coming to Chelsea Place just over a year ago, she was a stay-at-home mom. She is 33 years old, married, and has three young children. She was a shelter child when she was a teenager. Her mother never married and after at least ten years of depression committed suicide. Her youngest son gets in fights at school and she frequently has to leave work to pick him up and take him home to their small apartment. Falangen worries that someday she might follow her mother to an early grave. She has a BA in human services.

Wade Kotur, the third associate manager, has his BS in psychology. He is 29, single, has considerable college debt, and thinks he will never get married and have children. Both his parents abused him when he was young and he sees a therapist every week. He selects and supervises the shelter residents. This includes ensuring that house rules are followed, providing crisis counseling, and making referrals for the men who need job training, medical attention or transportation. His job also involves distributing mail (men are allowed to use Chelsea Place as their temporary legal residence), and helping the shelter men find affordable housing when their residency term expires. He has been with Chelsea Place for two years and loves working with the residents.

For the most part, the residents obey the rules because they are grateful for the opportunity to be here. Minor problems arise once in a while, like failing to clean up or coming in a few minutes past 9:30 PM, but a warning usually is enough to prevent a reoccurrence. Recently, however, the problems have multiplied. Based upon the following complaints that house 
manager Mullins has received in the last month, there seems to be considerable ethical egoism at the shelter, and the shelter mission seems to have been forgotten.

\section{THE COMPLAINTS}

1. A repeat resident claimed the source of his recent head lice was the shelter.

2. One resident complained that the shelter would not stay open long enough at night for him to get a temporary janitorial job.

3. Another man claimed his shoes had been stolen by another resident.

4. Volunteers have been taking home items that were donated to the shelter.

5. A resident needed a service dog, but manager Kotur would not allow it.

6. A resident complained that Kotur took away his cane because it was thought to be a dangerous weapon.

7. The volunteers who serve the food have been denying "seconds" that used to be allowed.

8. One day a volunteer who managed the lottery asked the two lottery winners (both Hispanic) what their names were and then told them that there were no beds. The volunteer apparently told them this with no emotion or compassion.

9. One resident claimed that associate manager Kotur made him wait over an hour to get his mail even though the resident could see it on the manager's desk when he asked for his mail.

10. Two volunteers complained that several residents were hitting them up for money.

11. One resident believed he should not have been "kicked out" simply because he smoked pot in the TV area.

12. Four volunteers complained that there were not enough volunteers to handle the number of walk-ins during Thanksgiving.

13. The architect on the Board threatened to push for the house manager's resignation if he didn't raise the amount of financial donations by at least $\$ 50,000$ in six months.

14. One of the small business owners on the Board did not like the rumor she heard that the shelter had taken in a transgendered person.

15. The local Legal Aid Society complained that they were receiving too many requests for legal work like restraining orders and divorce work or child custody issues.

16. The Legal Aid lawyers also complained that the cafeteria, where they consulted with their clients, was too loud, because that is where the residents could entertain their visiting children or friends.

17. The professor on the Board complained that students she had referred for internships were not getting anything meaningful to do and were not learning anything.

18. A person wanting to donate food and clothing claimed he was given erroneous donation times and directions to Chelsea Place by the volunteer who answered the phone.

19. At least five residents who had left the shelter claimed the affordable housing information given to them by associate manager Kotur was inaccurate and out-of-date.

20. One resident was complaining that management was forcing him to attend the church services.

The staff did not like hearing these complaints. When house manager Mullins held a management meeting to discuss the problems, the three associate managers pointed to his lack of availability as the cause and claimed he wasn't interested in what they did. When the manager asked the associates about their specific jobs, they each responded that they were performing their job as best they could. If there were problems with the volunteers, for example, Kate Falangen said that was Billy Kimber's responsibility, not hers. The meeting terminated with all four of them blaming each other. Mullins did not know how he was going to communicate these problems to the Board of Directors. How would they respond? 


\section{DISCUSSION QUESTIONS}

1. Identify and explain the "ethical egoism" at the Chelsea Place Shelter.

2. What seems to be the major problem here? What should happen now?

3. As you look at the social actors in this case, how are they affected by their personal histories and the larger contexts in which they are acting?

4. Do you see any exploitation and misuse of power in this case? Explain.

5. How is this agency (social system) out of balance? Which units are not functioning properly?

6. How should the complaints be handled? Who should handle them?

7. Which of the three associate managers has the most difficult job? Explain.

8. What are the chances that Chelsea Place can return to the well-run and respected place it once was?

9. Why are temporary shelters like this necessary? Do they do more harm than good? Do they detract from solving the bigger structural issues? How so?

10 . What are the obstacles to getting more affordable housing in needy areas? (Note: Refer to Henry et al. 2018)

11. What are the obstacles to obtaining more affordable health care? (Note: Refer to Waegemakers et al. 2014)

12. Do you see any discrimination in this case? If so, where?

13. Which of the social work code of ethics are broken in this case?

14. How is working with volunteers different than working with paid staff?

15. Describe the interconnections between the five social institutions (religion, education, family, politics and economics) as they relate to Chelsea Place.

16. Describe the communication at the shelter.

17. How do you imagine the shelter men see themselves?

\section{COMMENTS}

The goal of the social sciences is to discover the "truth" about the objective world. One way to do this and advance the social sciences is to offer and apply theory to see if it succeeds in its goal of explaining something. As Collins (1985) wrote, this world exists independently of our imaginations. Yet, although some would argue with this, we have to be able to see or feel it to know the world exists. One way of seeing the world is through sociology. The "sociological eye" (Collins 1998) can see through three lens, or three schools of thought: conflict theory, structural- functionalism and symbolic interactionism.

Conflict theorists emphasize that the social order is made up of individuals and groups competing with each other to advance their own interests over others (Collins 1985). The macro focus of this approach would explain homelessness as being a result of social conflict, and the homeless are the vulnerable subordinate group, or underclass, that loses power in the struggle over domination of goods and services. For conflict theorists like Marx (1977), economics explains human culture, politics and law. Some people believe that established religions further this subordination by disguising their desire for domination by offering charity to the oppressed and disenfranchised to relieve their pain and thus lessen the thirst of the homeless for conflict. The micro theorists of this conflict tradition would analyze the Chelsea House Shelter case as a microcosm of the larger world order. Whether they are macro or micro conflict theorists, their call to action and their weapon to be used in resource mobilization/distribution would be based on this ideology.

The second sociological tradition, structural-functionalism, is more conservative. Represented best by Durkheim (1964), their method of explaining the social order is to focus on the conditions under which things, like homelessness, happen and compare these with social 
conditions under which homelessness does not happen. The focal point of analysis is the five social institutions: family, religion, politics, economics and education. These institutions provide societal structure and operate as a system, and the system runs smoothly and orderly when they each do their intended job. However, when one or more of the institutions is broken and not serving its function another system has to pick up the responsibilities of the one that is broken so that equilibrium can be restored. For example, when the economic system fails to benefit a certain group then religion has to ease the burden placed on that group. This sociological lens can be macro and focus on the large picture of world homelessness or focus on the micro picture of a homeless shelter like Chelsea House where the units of the organization are not running smoothly and order must be regained. Parsons (1951) argued that to change the broken system basic cultural values that have been internalized by individuals have to be changed.

Symbolic interactionism is the third and most micro sociological perspective. There are many varieties of this tradition (Lewis and Smith 1980), but the ones most applicable to Chelsea House would focus on the homeless residents as deviants and "outsiders" (Becker 1963) and marginalized members of society. These symbolic interactionists would study how the residents see themselves (Goffman 1963), how they internalized the expectations and feedback from society, their "generalized other" (Mead 1967), and why they view themselves as stigmatized (Goffman 1959). The symbolic interactionists would also look at the methods and patterns of communication (Goffman 1963) between the Chelsea House residents and the staff, the staff and the outside community, the residents and the community and the staff members communicating with each other. Instead of the "generalized other," Goffman believed that how people interpret each other and how people interact is very much dependent on the social situation and in different social spaces. In other words, people have multiple selves.

These three sociological traditions have framed the questions at the end of the Chelsea House Shelter for Homeless Men case. What this paper offers is an invitation for the reader to explore the problem of homelessness in general and more specifically at Chelsea House. In addition, the hope is that the issue of ethical egoism (self-interested behavior) will be discussed as either a learned cultural value or as an innate human trait that impedes the goal of justice and dignity for all. Thus, what is getting in the way of solving the world problem of homelessness? Are the solutions too costly, too complicated or too political? According to consequential moral theorists, the right action to take in addressing homelessness and the resulting lack of dignity felt by this vulnerable sector of society is to find a set of solutions that bring the most good to the greatest number of people. Is this accomplished by following the easiest, and least expensive, route of providing homeless shelters? And there is certainly political disagreement over the usefulness, cost and placement of these. If they are provided, the shelters should set an example of the moral high ground. They are temporary solutions, but should be run properly.

\section{References}

Becker, H. S. (1963). Outsiders: Studies in the sociology of deviance. Glencoe, Ill: Free Press.

Bentham, J. (1878, [1789]). Of the principle of utility. In An Introduction to the Principles of Morals and Legislation (pp. 1-7). Oxford, UK: Clarendon Press.

Boyle, C. J., Beardsley, R. S., Morgan, J., \& Rodriguez de Bittner. (2007). Professionalism: A determining factor in experiential learning. American Journal of Pharmaceutical Education, 71 (2), 1-7. DOI: 10.5688/aj710231.

Brinca, J., \& Menezes, N. (2019). The influence of social sciences on the professionalism of social work: A case study in a treatment team with consumers of psychoactive substances. Advances in Social Sciences Research Journal, 6(9), 24-31. DOI: 10.14738/assrj.69.6844. 
Chamie, J. (2017). As cities grow, so do the numbers of homeless. Yale Global Online. http://yaleclobal.yale.edu/content/cities-grow-so-do-numbers-homeless.

Collins, R. (1985). Three sociological traditions. New York, NY: Oxford University Press.

Collins, R. (1998). The sociological eye and its blinders. Contemporary Sociology, 27(1), 2-7. DOI: $10.2307 / 2654697$.

Culhane, D., Metraux, S., \& Byrne, T. (2011). A prevention-entered approach to homelessness assistance: A paradigm shift. Housing Policy Debate, 21(2), 295-315. DOI: org/10.1080/10511482.2010.536246.

DeVerteuil, G., May, J., \& von Mahs, J. (2009). Complexity not collapse: Recasting the geographies of homelessness in a "punitive" age. Progress in Human Geography 33(5), 646-666. DOI: 10.1177/0309132508104995.

Durkheim, E. (1951). The division of labor in society. New York, NY: The Free Press.

EOH. (2018). Homelessness services in Europe: EOH (European observatory on homelessness) Comparative studies on homelessness. Brussels, Belgium: European Federation of National Associations Working with the Homeless.

Goffman, E. (1959). The presentation of self in everyday life. Garden City, NY: Doubleday \& Company.

Goffman, E. (1963). Stigma: Notes on the management of spoiled identity. New York, NY: Simon \& Schuster.

Habitat. (2015). Global homelessness statistics. Homeless World Cup. http://homelessworldcup. org/homelessness-statistics/

Henry, M., Mahathey, A., Morrill, T., Robinson, A., Shivji, A., and Watt, A. (2018). The 2018 annual homeless assessment report (AHAR) to congress. Washington, DC: Department of Housing and Urban Development. https://www.hudexchange.info/resources/documents/2018-AHAR-Part-1.pdf.

ISBIS. (2019). Community housing \& homeless shelters in the US - number of businesses. IBISWorld. https://www.ibisworld.com/industry-statistics/number-of-businesses/community-housing- homeless-sheltersunited-states.

Institute of Medicine US Committee on Health Care for Homeless People. (1988). Who are the homeless. Homelessness, Health, and Human Needs. Washington, DC: National Academies Press.

Jensen, D. (2014). Notes from the CFT library: Teaching and the case method.

$\mathrm{http}: / /$ cft.vanderbilt.edu/library/articles-and-essays/the-reading-forum/notes-from-the-cft-1.

Leon, A., \& Kraul, C. (2017, March 28). Peru's brutal season of floods leaves 94 dead, 7000 homeless. Los Angeles Times. https://latimes.com/world/mexico-americas/la-fg-peru-floods-20170328-story.html.

Lewis, J. D. (1980). American sociology and pragmatism: Mead, Chicago sociology, and symbolic interaction. Chicago, IL: University of Chicago Press.

Mackie, P. (2015). Homeless prevention and the Welsh legal duty: Lessons for international policies. Housing Studies, 30(1), 40-59. DOI:/org/10.1080/02673037.2014.927055.

Marx, K. (1977) Capital: A critique of political economy. New York, NY: Random House.

May, J., Johnsen, S., \& Cloke, P. (2007). Alternative cartographies of homelessness: Rendering visible British women's experiences of "visible" homelessness. Gender, Place and Culture, 14(2), 121-140. DOI: 10.1080/09663690701213677.

Mead, G. H. (1967). Mind, self and society. Chicago, Ill: University of Chicago Press.

Mill, J. S. (1879). What utilitarianism is. In Utilitarianism, $7^{\text {th }}$ Ed. (Chapter II). London, UK: Longmans, Green, and Co.

Packard, T., \& Austin, M. (2009). Using a comprehensive case-based examination to evaluate and integrate student learning in social work administration. Journal of Teaching in Social Work, 29, 204-215. DOI:

10.1080/08841230802240886.

Parsons, T. (1851). The social system. Glencoe, Ill: Free Press.

Reynolds, L. (2018). Homelessness in Great Britain - the numbers behind the story. Shelter The Housing and Homelessness Charity. London, UK. https://england.shelter.org.uk/professional_resources/policy and_research/policy_library_folder/research_homelessness_in_great-britain.

Rivas, R. \& Hull, G. (2004). Case studies in generalist practice, $3^{\text {rd }}$ Ed. Belmont, CA: Brooks-Cole.

Shelter. (2019). Homelessness statistics in Scotland. The Scottish Government Publications. Edinburgh, Scotland. 
Surkes, S. (2018, January 15). 25,000 people said homeless in Israel; social services treat under $10 \%$ of them. Times of Israel. https://www.timesofIsrael.com/social-services-treating-under-10-0f-the-25000-said to be homeless-in-israel/

Toro, P. A., (2007). Toward an international understanding of homelessness. Journal of Social Issues, 63(3), 1-481. DOI: org/10.111/j.1540-4560.2007.

Toro, P. A., Hobden, K. L., Durham, K. W., Oko-Riebau, M., and Bokszezanin, A. (2014). Comparing the characteristics of homeless adults in Poland and the United States. American Journal of Community Psychology, 53(1-2), 134-145. DOI: org/10.1007/s10464-014-9632-8.

USCM (1987). Current issues. United States Conference of Mayors annual report and forecast. Washington, DC: IHS.

Vaughn, L. (2008). Doing ethics: Moral reasoning and contemporary issues. New York, NY: W. W. Norton \& Company, Inc.

Waegemakers Schiff, J., \& Schiff, R. A. (2014). Housing first: Paradigm or program? Journal of Social Distress and the Homeless, 23(2), 80-104. DOI: 10.1179/15736358X14Y.0000000007.

Wilson, S. \& Fitzpatrick, S. (2010). The impact of devolution: Housing and homelessness. York, UK: Joseph Rowntree Foundation. 